Cahiers $d u$ MONDE RUSSE

\section{Cahiers du monde russe}

Russie - Empire russe - Union soviétique et États indépendants

48/2-3 | 2007

Les résonances de 1905

\title{
Pravitel stvo i problema zakonnosti v 1904-1917 gg.
}

\section{Ekaterina A.PRAVILOVA}

\section{OpenEdition \\ Journals}

Édition électronique

URL : https://journals.openedition.org/monderusse/8996

DOI : 10.4000/monderusse.8996

ISSN : $1777-5388$

Éditeur

Éditions de l'EHESS

Édition imprimée

Date de publication : 15 avril 2007

Pagination : 209-220

ISBN : 978-2-7132-2147-7

ISSN : $1252-6576$

\section{Référence électronique}

Ekaterina A.PRAVILOVA, « Praviteĺ stvo i problema zakonnosti v 1904-1917 gg. », Cahiers du monde russe [En ligne], 48/2-3 | 2007, mis en ligne le 01 janvier 2007, consulté le 04 septembre 2022. URL http://journals.openedition.org/monderusse/8996; DOI : https://doi.org/10.4000/monderusse.8996 


\title{
CAIR N
}

chercher : repérer : avancer

Cet article est disponible en ligne à l'adresse :

http://www.cairn.info/article.php?ID REVUE=CMR\&ID NUMPUBLIE=CMR 482\&ID ARTICLE=CMR 4820209

\section{Pravitel' stvo i problema zakonnosti v 1904-1917 gg}

\author{
par Ekaterina A.PRAVILOVA
}

| Editions de l'EHESS | Cahiers du monde russe

2007/2-3 - Vol 48

ISSN 1252-6576 | ISBN 9782713221477 | pages 209 à 220

Pour citer cet article :

- A.PRAVILOVA E., Pravitel' stvo i problema zakonnosti v 1904-1917 gg, Cahiers du monde russe 2007/2-3, Vol 48, p. 209-220.

Distribution électronique Cairn pour les Editions de l'EHESS.

(C) Editions de l'EHESS. Tous droits réservés pour tous pays.

La reproduction ou représentation de cet article, notamment par photocopie, n'est autorisée que dans les limites des conditions générales d'utilisation du site ou, le cas échéant, des conditions générales de la licence souscrite par votre établissement. Toute autre reproduction ou représentation, en tout ou partie, sous quelque forme et de quelque manière que ce soit, est interdite sauf accord préalable et écrit de l'éditeur, en dehors des cas prévus par la législation en vigueur en France. Il est précisé que son stockage dans une base de données est également interdit. 


\author{
EKATERINA А. ПРАВИЛОВА
}

\title{
ПРАВИТЕЛЬСТВО И ПРОБЛЕМА ЗАКОННОСТИ В 1904-1917 ГГ.
}

Понятие «законность», кажется, не нуждается в пояснении: обычно читатель, встречая его в тексте, не тянется за толковым или этимологическим словарем. Это понятие относится к категории тех, которые имеют как общегражданское, так и строгое юридическое значение, причем и то и другое менялось со временем. В XVIII- начале XX вв. концепция «законности» определялась по-разному, исходя из правовых и политических идей, лежащих в основе мировоззрения политического деятеля или программы партии, группы или общественного движения. Соответственно, по-разному представлялись и необходимые для обеспечения законности институциональные гарантии (законность всегда подразумевала необходимость ее охранения). Кризисы и переломы в политической истории приводили и к перемене смысловой нагрузки термина, отношения к закону, веры в способность различных институтов гарантировать соблюдение прав личности и общества. Одним из таких критических периодов, выявивших отношение правительства и обществ а к закону, являлась революция 1905-1907 гг. ${ }^{1}$

В этом эссе я попытаюсь, во-первых, описать среду правовых теорий и идей, сформировавшихся в России к концу хІх века под влиянием западноевропейских концепций. Употребляемые политиками и авторами законодательных актов 1904-1907 гг. понятия были порождены этой средой, и, следовательно, к интерпретации политических реформ или их проектов необходимо подходить с учетом разных смысловых нагрузок правовых терминов. Во-вторых, предстоит оценить значение революции 1905-1907 гг. в трансформации смыслов понятия «законность» и место этой доктрины в политическом лексиконе России после первой революции. С этой целью

1. Некоторые положения этой статьи отражены в монографии автора «Законость и права личности. Административная юстиция в России», СПб.: Образование-Культура, 2000. 
я проанализирую программы институциональных реформ, призванных «охранять» законность в государстве - реформы Сената и административных судов в период 1907-1916 гг. Именно в этих проектах, на первый взгляд кажущихся продуктом казуистических упражнений юристов, отражались теоретические и политические представления общества и правительства о том, что такое законность в самодержавном государстве.

Для второй половины хІх века выбор различных концепций «правового государства» был довольно широк, хотя для российских юристов основными источниками являлись европейские континентальные, и, прежде всего, немецкие доктрины. Теоретическим образцом либеральной теории Rechtsstaat для русских юристов служили сочинения немецких юристов, прежде всего Роберта Моля, особенно популярные в России в середине ХІх столетия. Главная идея сочинений Моля состояла в необходимости ограничения цели и сферы деятельности государства, в том числе правовыми нормами. Государство не должно быть всеобъемлюще: существует сфера деятельности человека и общества, куда его вмешательство не должно распространяться. Концепция Моля в основном не затрагивала проблемы организации институтов: главный акцент был сделан на переосмыслении цели государственной деятельности. Последователи Моля развили его идею, предложив все же и определенные институциональные средства обеспечения правового режима. В прикладном юридическом смысле это означало: должны существовать инструменты, препятствующие проникновению государства в область права индивидуумов. Такими инструментами являлись, прежде всего, представительные учреждения и суды, контролирующие деятельность администрации (общие или специальные административные, но непременно независимые от администрации). Представителигосударства - чиновники всех уровней администрации должны были подлежать судебной ответственности за нарушение прав личности и закона, наравне с частными лицами. Доктрины конституционализма и общего правосудия, равенства государства и частного лица перед законом выражали главную идею либеральной модели правового государства.

Формальная (или бюрократическая) теория правового государства, в отличие от либеральной, основана на безусловном доверии к государственной добродетельности и святости закона. Она не призывает к ограничению государственной активности. Главный акцент сделан на формальном соблюдении законов в государстве и подчинении бюрократии законам, источником которой является законодательная власть ${ }^{2}$. Если либеральная теория правового государства отталкивается от права личности, защищаемой законом от неправосудия, в том числе государственного, то формальная

2. Одним из главных теоретиков этого рода «бюрократического» либерализма был РудольфГнейст, чрезвычайно популярный в России 1870-1890-х гг. По словам Л. Кригера, Гнейст верил в том, что «свобода гарантирована объективными самоограничивающими законами, издаваемыми по инициативе монарха или бюрократии согласно существующей конституции и при пассивном участии общества в реализации этих законов на местах». Leonard Krieger, The German Idea of Freedom. History of a Political Tradition, Boston: Beacon Press, 1957, p. 357. 
теория исходит из абстрактного, не связанного с правами человека, понятия законности. Во второй половине ХІХ века формальная концепция правового государства возобладала в немецкой юриспруденции и являлась основой для институциональных реформ 1870-1880-х гг. в бисмарковской Германии (реформ местного управления и административной юстиции). В отличие от либеральной концепции, одним из главных требований которой являлось установление конституционной монархии, формальная теория допускала возможность гарантировать законность при любой форме правления путем установления строгого контроля за соблюдением правил. Главное, чтобы не нарушался закон: неважно какой, кем и как изданный. Враг «законности» в этом смысле - бюрократический произвол. Следовательно, защита законности была выгодна и необходима прежде всего государству - для обеспечения правильной работы механизма. Что для этого нужно? Создать специальные институты судебно-административного контроля, которые, с одной стороны, позволяли бы пресекать злоупотребления бюрократов, а с другой стороны не давали бы возможности частным лицам и обществу вмешиваться в процесс управления. Административные суды, подчиненные администрации, стали продуктом реализации этой доктрины в Германии 1870-1880-х гг.

Влияние немецкой концепции административной юстиции и правового государства распространилось далеко за пределы империи, хотя в конце ХІХ века континентальной Европе ей приходилось конкурировать с растущим влиянием французских юристов (Э. Лаферрьера, М. Ориу, О. Окок, Д. Дюги и др.). Развитие французской правовой и политической доктрины в конце ХІХ века представляло собой новый виток в эволюции либеральной концепции. Ж.-М. Редор описывает эту эволюцию как движение от «законного государства к правовому» ${ }^{3}$. Установление республики, по мнению юристов, решило проблему конституционного развития Франции, но не решило проблему законности. Истинный либерализм состоял в том, чтобы, следуя идее Р. Моля, защитить гражданина не только от администрации, но и от государства вообще, в том числе представительных институтов. «Система законного государства оказалась не соответствующей необходимости контроля новых форм государственного воздействия: парламентский контроль администрации функционировал только в политической области, гарантии политических прав граждан не защищали их ни от расширения сферы административной деятельности, ни от произвола управления» ${ }^{4}$. Правовое государство (L'État de droit), таким образом, было следующим, после конституционного (L’État légal) этапом последовательной эволюции европейских политико-правовых доктрин.

Конечно, нельзя не упомянуть и об англо-американской правовой традиции и концепции Rule of Law, имевшей большое влияние в Европе. Английские юристы сознательно и с энтузиазмом дистанцировались от континентальной традиции права, подчеркивая, что в то время как европейские теоретики изобретали специальные режимы для контроля управления, в Англии

3. M.-J. Redor, De l'état légal à l'état de droit : l'évolution des conceptions de la doctrine publiciste française : 1879-1914, P., 1992.

4. Ibid., p. 133 . 
все граждане и представители государства в равной степени подчинялись верховному контролю суда. Принцип единой юстиции логически дополнял английскую правовую модель, основанную на конституционализме и самоуправлении.

Российская правовая философия хІх столетия развивалась под сильным влиянием конкурирующих европейских теорий. Юристы и политики имели доступ к разнообразию правовых и политических концепций и зачастую определяли свою принадлежность к той или иной юридической платформе на основании того, какие идеи они разделяли. С конца 1870-х гг. немецкие юридические теории, наряду с экономическими концепциями оказались наиболее популярными среди русских ученых. Правительственные инициативы в области реформы управления и экономики отчасти отражали их теоретические предпочтения. Немецкая теория Rechtsstaat была, конечно, сильно «правее» и консервативнее английских и французских либеральных идей популярных в 1850-60-е гг..$^{5}$ но, в то же время, как показывает Х. Уилан, она упорядочивала самодержавный режим в период контрреформ 1880-1890$\mathrm{x}$ гг. ${ }^{6}$ Главная идея немецкой правовой философии и политэкономии - о первостепенной роли государства и его институтов в развитии общества, как нельзя лучше соответствовала политическим планам правительства и разделялась лучшими представителями академической среды.

K концу хІх века в правой консервативной публицистике в России оформился еще один вариант концепции «законности», претендовавший на самобытность. «Славянофильская» теория основывалась на тезисе о том, что законность органически присуща самодержавию как политическому строю, но, между тем, для защиты самодержавной власти необходимо изобрести средства борьбы с бюрократическим произволом. Одним из наиболее типичных образцов программы правовых реформ этого направления являлось сочинение П.Н. Семенова «Самодержавие как государственный строй» (1905). Автор утверждал, что для обеспечения «важнейшего требования самодержавия законности во всем управлении» необходимо было препятствовать «расхищению» самодержавной власти бюрократией: положить в законе более точную грань между законом и повелением, установить контроль Сената за законодательством, ограничить возможность единоличных действий министров, предоставив им обращаться в коллегиальный Сенат, а также наделить Сенат высшей властью, соответствующей статусу, данному ему Петром. Парадоксальным образом требования либеральных юристов и консервативных публицистов в вопросе о реформе Сената совпадали: и те, и другие желали восстановления этого института. Среди сторонников реформы Сената были А.Д. Градовский, С.Ф. Шарапов, К.П. Победоносцев и многие другие. Для либералов-западников Сенат был прообразом административного

5. Frederic Starr, Decentralization and Self-government in Russia, Princeton UP, 1972, p. 51-110.

6. См.: Heide W. Whelan, Alexander III \& the State Council : Bureaucracy \& Counter-Reform in Late Imperial Russia, Rutgers UP, 1982. 
суда. Для консерваторов - «хранителем законности» и воплощением идеала русской государственности ${ }^{7}$.

Итак, к концу хІх века сформировался ряд концепций и интерпретаций понятий «законность». Рассуждения о необходимости охранять эту законность стали повсеместны, что заставило В.П. Мещерского протестовать против «культа законности», вносившего «смуту в русскую умственную жизнь» ${ }^{8}$. Тем не менее, правительство не могло игнорировать призывы публики охранять закон и бороться с бюрократическим произволом. Поэтому в заявлении манифеста 12 декабря 1904 года обещания бороться за установление законности не было ничего риторического. Другой вопрос: какую же из трех «законностей» имел в виду инициатор манифеста, министр внутренних дел князь П.Д. Святополк-Мирский, и какова была дальнейшая судьба этого обещания?

Несмотря на разнообразие европейских вариантов реформ и концепций «законности», имевшееся в его распоряжении, П.Д. Святополк-Мирский отдал предпочтение славянофильскому варианту. По свидетельству C.Е. Крыжановского, которому была поручена подготовка текста манифеста, источниками программы П.Д. Святополка-Мирского в вопросе о судебноадминистративной реформе являлись сочинения правового публициста, известного своими славянофильскими убеждениями С.К. Глинки-Янчевского. Глинка-Янчевский защищал концепцию «народного самодержавия», призывая укрепить самодержавную законность реформой Сената - восстановления его значения, данного Петром Великим. Именно на сочинения Глинки-Янчевского, как на образец программы правовых реформ, указывал СвятополкМирский Крыжановскомуํ․ Первый пункт манифеста должен был заявить о намерении власти созвать представительство, а Сенат, видимо, должен был дополнить весьма своеобразную государственную конструкцию «народного самодержавия» с представительством.

Эклектическое сочетание первоначально проектируемого первым пунктом манифеста созыва представительства с законностью в славянофильском духе было упразднено: накануне подписания манифеста, как известно, Николай II вычеркнул из него первый пункт ${ }^{10}$. Таким образом, вся главная смысловая нагрузка теперь легла на первый пункт о законности. После подписания манифеста П.Д. Святополк-Мирский потерял инициативу в реализации программы реформ, а вместе с тем,- в январе 1905 г., - и пост министра

7. Грань, отделявшая Россию старую от новой, ранее всегда совпадавшая с началом петровского царствования, ныне сдвигалась на царствование Александра I. Петровская «коллегиальность», заимствованная из европейского камерализма, отождествлялась с соборностью: Сенат выглядел вполне «русским», по сравнению с введенными Александром I министерствами.

8. «Законность или самодержавие», Гражданин, №1, 1896.

9. С.Е. Крыжановский, Воспоминания, Берлин, б г., с. 16.

10. Перипетии политической борьбы в 1904-1905 гг. подробно описаны в монографии Р.Ш. Ганелина, Российское самодержавие в 1905 г.: Реформы и революция, СПб.: Наука, 1991. 
внутренних дел. Подготовка программы мер по выполнению первого и других пунктов манифеста была поручена Комитету министров, возглавляемому С.Ю. Витте.

К интерпретации пункта о сохранении законности Витте подошел с иными, нежели П.Д. Святополк-Мирский, взглядами. Надо отметить, что текст первого пункта допускал возможность его свободного истолкования. В манифесте говорилось о необходимости «принять действенные меры к охранению полной силы закона, - важнейшей в самодержавном государстве опоры престола, - дабы ненарушимое и одинаковое для всех исполнение его почиталось первейшею обязанностью подчиненных нам властей и мест, неисполнение же ее неизбежно влекло законную за всякое произвольное действие ответственность, и в сих видах облегчить потерпервшим от таких действий лицам способы достижения правосудия» ${ }^{11}$. Эту декларацию можно было бы истолковать по-разному: и как обещание дать право частным лицам привлекать всех чиновников к суду за нарушение закона, и как намерение навести порядок в бюрократии с помощью внутреннего административного контроля.

Программа реализации этого пункта Витте оказалась намного более либеральной, чем программа Святополка-Мирского. В сущности, Витте попытался извлечь из этого обещания максимум институциональных реформ - это могло бы каким-то образом скомпенсировать отсутствие пункта о представительстве. Не реформа Сената в славянофильском духе (каким было представление о законности бывшего министра внутренних дел), а институциональные реформы в духе формальной концепции правового государства - такова была концепция преобразований. Очевидно, первым пунктом в программе реформ значилось определение границ «закона» и административного распоряжения ${ }^{12}$, организация административной юстиции и усовершенствование порядка судебного преследования чиновников за должностные преступления ${ }^{13}$. Любопытно, что в декларации о реформах присутствует и упоминание о «петровском Сенате» - знак влияния популярных идей возрождения этого учреждения или остатки плана СвятополкаМирского. За эту эклектику (смешение двух совершенно разных концепций) не искушенный в юриспруденции Витте заслужил упреки со стороны оценивавших программу реформ юристов (Н.И. Лазаревский отметил, что предложения Витте противоречили всем «положениям науки») $)^{14}$.

11. ПСЗ III, T.XXIV, № 25495.

12. Эта реформа рассматривалась как сама собой разумеющаяся в контексте альтернативности конституционализму: в случае введения представительства искусственное разделение закона и указа теряло бы смысл. То, что проблема «указа и закона» не исчезла после введения представительства, является ярчайшим доказательством псевдоконституционности строя.

13. См. записку о «вопросах, подлежащих, по мнению председателя Комитета министров, разрешению Комитета по пункту 1-му именно Высочайшего указа 12 декабря 1904 года», Российский государственный исторический архив, ф. 1243, оп. 1, доп. к т.xvi, д. 1, л. 7-7об.

14. Н.И. Лазаревский, «Соображения Комитета министров о преобразовании административной юстиции», Право, № 6, 1905, с. 386. 
Итак, в программе Витте образца начала 1905 г.- в период между манифестами 12 декабря 1904 г. и 17 октября 1905 г.- «законность» выступала альтернативой конституционализму ${ }^{15}$. Как только стало ясно, что конституционных реформ не избежать, Витте потерял всяческий интерес к разработке обещанных реформ. Созданное по решению Комитета министров в январе 1905 г. Особое Совещание А.А. Сабурова подготовило проекты реформ Сената, и в апреле 1906 г. Совещание было закрыто. С практической точки зрения «законность» в формальном смысле оказывалась ненужной Витте рассчитывал, что реформы перешагнули эту ступень: от формальной законности как суррогата конституционализма (перефразируя высказывание К.П. Победоносцева - «Сенат в России - это замена конституции» ${ }^{16}$ ) к конституционному самодержавию. Действительно, предполагаемыек созданию представительные учреждения должны были, помимо законодательных функций, осуществлять контроль за административной деятельностью.

В годы революции идеи реформы Сената, организации административной юстиции и введения ответственности должностных лиц (именно эти пункты составляли институциональное содержание «проблемы законности») временно отступили на периферию общественного внимания. Впрочем, требования проведения реформ во имя законности появились в программах первых политических партий, наряду с установлением гарантий неприкосновенности личности, пересмотром Положения об усиленной охране, реформой суда и местного самоуправления, а также усилением ответственности должностных лиц. Сражаться за законность намеревались, прежде всего, партии и политические группы центристской ориентации ${ }^{17}$. «Группа центра» в Государственном Совете, «Партия 17 октября» (преобразование Сената вошло в программу реформ, принятую на партийной конференции «Союза 17 Октября» в октябре 1907 г.), позднее - прогрессисты активно выступали за реформу Сената и административных судов. Их теоретический правовой идеал укладывался в рамки формальной концепции правового государства, а вера в возможность обеспечения законности при существовавшем самодержавноконституционном строе выражалась в настойчивых требованиях к правительству изменить институциональные формы контроля за управлением.

Отношение кадетов к проблеме законности было несколько иным. В отличие от октябристов и прогрессистов, активно эксплуатировавших идею защиты законности, кадеты большее внимание уделяли политическим свободам и защите гражданских прав личности. Кадеты вносили свои проекты, предполагаемые организацию административной юстиции, но их модель сильно отличалась от октябристской: она основывалась на английской

15. Н.С. Таганцев прокомментировал программу реформ «диалектической попыткой С.Ю. Витте сочетать самодержавие с законностью». Н.С. Таганцев, Пережитое, Пг., 1919, вып. 1, с. 73

16. Я.Г. Есипович, Записки сенатора, СПб., 1909, с. 86.

17. Первая попытка после закрытия совещания А.А. Сабурова поднять вопрос о реформе Сената была предпринята в начале 1907 г. возглавляемой тем же Сабуровым Группой центра Гос. Совета. Предложение было отклонено. 
теории Rule of law и юридической концепции общего права (все, в том числе и государство, подлежат юрисдикции общих судов). Разнообразие представлений политических партий центра и оппозиции отразилось и в думской законодательной практике.

Поскольку близкие по сфере деятельности думские комиссии и подкомиссии контролировались разными фракциями, на рассмотрение Думы вносились различные проекты организации административной юстиции. Октябристы были «ответственны» за реформу Сената, и в Думе III созыва судебная комиссия состояла преимущественно из октябристов и близких к ним депутатов. В проекте, подготовленном думской подкомиссией и обсужденном на партийном съезде «Союза 17 октября», Сенат представал как «Верховный хранитель и толкователь закона и Высший административный суд» ${ }^{18}$. Этот проект чем-то сильно напоминавший идеи «петровского Сената» (он отличался от правительственных проектов тем, что предоставлял Сенату более независимый статус) конкурировал с проектом Министерства юстиции (в нем Сенат выступал как внутреннее орудие административного надзора) и, с другой стороны, критиковался кадетами.

Кадеты представляли себе Сенат именно как аналог западноевропейских административных судов, и октябристские идеи «петровского Сената»с их точки зрения были анахронизмом ${ }^{19}$. Впрочем, своего собственного проекта реформы у кадетских юристов не было: можно предположить, что эта реформа не казалась кадетам достаточно значительной. Во-первых, П.Н. Милюков полагал, что правительство «само пойдет» на реформу административной юстиции $^{20}$ (бороться за это было как-то неинтересно), во-вторых, борьба за законность в форме создания институциональных сдержек бюрократического произвола не совсем соответствовала их теоретическому представлению о правовом государстве. В центре внимания кадетских юристов была проблема конституционализма, но тогда, когда речь шла о взаимоотношениях государства и личности, кадеты не полагались на административный суд: они требовали издания закона о неприкосновенности прав личности и привлечения всех чиновников к общему суду. Их теория правового государства исходила из двух главных посылок: конституционализма и защиты индивидуальной свободы. Реформы Сената и административных судов оказывались на втором плане. Конституционализм оказался «выше» законности в системе политических приоритетов оппозиции.

Правительство со своей стороны рассматривало проведение реформы Сената как выполнение данного в декабре 1904 года обещания. Идея создания

18. Основные тезисы и положения докладов 3-го Всероссийского съезда делегатов «Союза 17 октября», М., 1909, с. 8-9. Материалы подготовки реформы в Думе см.: РГИА (Российский государственный исторический архив), Библиотека. Коллекция печ. записок, № 69, с. 14; Государственная Дума, III Созыв, Сессия II, Комиссия по судебным реформам, Журнал заседаний, № 21, РГИА, ф. 1278, оп. 2, 1909, д. 3476, л. 140-141 об.

19. См.: Ф.Ф. Кокошкин, К вопросу о реформе Сената, М., 1908, с. 12, 14, 17.

20. Протоколь Центрального Комитета конституционно-демократической партии 1905-1911 2., т. 1, М., 1994, с. 148, 151, 550. 
гарантий законности, высказанная Сабуровским совещанием в 1905 г., оказалась одним из центральных пунктов программы государственных преобразований П.А. Столыпина. Лозунг «борьбы за закон» с самого начала деятельности премьер-министра занял центральное место в столыпинской риторике. Правительство стремилось перехватить у Думы инициативу в борьбе за законность, отвлечь внимание общества от думских запросов и продемонстрировать правовую добродетель. С другой стороны, оно было само заинтересовано в упорядочении деятельности подчиненных властей. Сенаторские ревизии в губерниях, реформа Сената, учреждение административных судов и пересмотр законодательства о должностных преступлениях - таков был наборинституциональных реформ, предполагаемых к реализации правительством Столыпина. Однако каково было все же содержание предполагаемых мер, к какой из названных нами концепций законности они относились?

О предоставлении Сенату независимого статуса административного суда не было и речи: Сенат, благодаря усовершенствованию его структуры, превращался в удобный инструмент внутреннего правительственного контроля за управлением и законодательством. Органы, охранявшие законность, должны были быть встроены в систему самой администрации. Бюрократическая законность в духе немецкой консервативной юридической концепции ХІХ века, снабженная риторикой «восстановления» правосудия, контрастировала с представлениями о законности как октябристов, так и кадетов.

B IV Думе идеи преобразования институциональной защиты законности вновь активно продвигали октябристы ${ }^{21}$ и прогрессисты ${ }^{22}$. Внесенный прогрессистами в марте 1913 года проект ${ }^{23}$, а также проект, поданный Министерством юстиции, обсуждался в комиссии по судебным реформам (преимущественно октябристской по составу). Реформа Сената оказалась одним из важнейших шагов в преобразовании судебно-административной системы, и о нем говорили и писали все. Октябристы с восторгом приветствовали идею восстановления величественного Сената как органа контроля за всем и вся; кадеты вновь критиковали проект за то, что его составители «забыли» об «обязанности» Сената «быть органом административной юстиции» ${ }^{24}$ и вместо того, чтобы придать ему цивилизованный европейский вид, нагрузили массой ненужных полномочий.

Позиция правительства в отношении сенатской реформы и проблемы законности, так же как и сам правительственный проект, почти не изменились

21. Этот вопрос, в частности, был обсужден на заседании бюро «Союза 17 октября» 4 марта 1913, ГАРФ (Государственный архив Российской Федерации), ф. 115, оп. 2, 1913, д. 3 , л. 24.

22. См: Съезд прогрессистов 11, 12 и 13 ноября 1912 г., СПб., 1913, с. 19. На состоявшемся 24 марта 1913 г. соединенном заседании бюро этих двух партий реформа Сената была признана первоочередной задачей, ГАРФ, ф. 115, оп. 2, 1913, д. 3, л. 24.

23. РГИА, ф. 1405 , оп. 532, д. 538.

24. Государственная Дума: Стенографический отчет: Созыв IV, Сессия II, СПб., 1914, ч. 2 , стб. 834 . 
с 1907 г. При обсуждении реформы в Думе в 1913 г. министр юстиции И.Г. Щегловитов выразил правительственную концепцию в духе модной в конце ХІх века славянофильской теории. Сенат, по мнению Щегловитова, был «учреждением совершенно своеобразным, самобытным, русским». Министр категорически отбросил модели правовых гарантий законности, вдохновленные западноевропейскими концепциями правового государства, заявив, что «начало законности в Российском государстве явилось... свободным проявлением высшей воли русских самодержцев» ${ }^{25}$. Попытки думцев подправить проект с тем, чтобы сделать Сенат более похожим на административный суд, независимый от власти, окончились поражением. Представления правительства и Думы о том, что такое законность, разошлись кардинальным образом. После долгих мытарств и многочисленных обсуждений, проект реформы Сената был утвержден уже только накануне революции, в декабре 1916 г.

Не менее ярко концептуальные противоречия в трактовке понятия «законность» проявились в обсуждении проектов создания местных органов административной юстиции. Правительство Столыпина уделяло особое внимание борьбе за законность местной администрации. Преодолевая некомпетентность губернаторов и Совета по делам местного хозяйства (членам которого приходилось объяснять значение термина «административный суд»), Столыпин настойчиво демонстрировал намерение правительства бороться за закон. Однако, как и в случае реформы Сената, выбранный путь обеспечения законности был весьма консервативным.

Из всего многообразия моделей организации административных судов, уже опробованных в практике европейских государств, автор проектов, И.Я. Гурлянд, отдал предпочтение прусской. Представляя проект местной реформы в Совет министров в 1907 г., Столыпин признал, что в вопросе административной юстиции можно было бы пойти и иным путем, но министр «не решился» предложить такую меру. Проект предлагал в сущности усовершенствовать институт жалобы, учреждая специальное судебное присутствие в губернских органах управления. «Всякое иное устройство» (очевидно, имелась в виду передача общим судам рассмотрения дел по искам к администрации), по словам проекта, «становилось бы в противоречие со всем ходом русского законодательства об управлении и с самим духом его» ${ }^{26}$.

Очевидно, предложенная Гурляндом прусская модель «ходу русского законодательства» не противоречила. В главных чертах проект Министерства внутренних дел почти полностью был основан на немецкой теории Rechtsstaat и административной юстиции: как в теоретической части, так и в институциональной (принципы организации административно-судных присутствий, принадлежащих ведомству Министерства внутренних дел).

25. Государственная Дума: Стенографический отчет: Созыв IV, Сессия II, СПб., 1914, ч. 2., стб. 808.

26. «О преобразовании учреждений губернского управления», Государственная Дума: Созыв II: Законопроекты, внесенные МВД, СПб., 1907, с. 77об. 
Немецкая доктрина правового государства Р. Гнейста, одним из главных элементов которой являлась административная юстиция, оказалась довольно удачным инструментом для П.А. Столыпина. Она переносила акцент с конституционных гарантий правосудия на бюрократическоправовые. Однако, эта трактовка понятия законности и способов ее защиты, очевидно, не совпадала с подходом либеральной оппозиции. Правительство демонстрировало прагматическое отношение к административной юстиции как средства обеспечения порядка в бюрократии. Либеральная часть Думы предлагала альтернативные варианты судебной защиты прав личности и правового контроля местного самоуправления ${ }^{27}$.

Уже в первых проектах конституционно-демократической партии упоминалось о намерении передать контроль за деятельностью земств независимым от администрации органам - специальным отделениям окружного суда (а отнюдь не подразделениям местной администрации, как предлагал Столыпин) ${ }^{28}$. Эта же идея была выражена в кадетском проекте реформы городского самоуправления, внесенном в IV Думу в 1913 г., однако члены комиссии по городским делам скорректировали проект, заменив окружной суд в качестве контрольной инстанции специальным смешанным судебно-административным присутствием. В том же 1913 г. прогрессисты внесли законопроект о земской реформе. В окончательной редакции он следовал кадетской идее - предоставить суду рассматривать проблемы законности деятельности администрации. Проекты реформы местного управления обсуждались Думой и правительством до конца 1916 года, но ни один из них не был реализован. Решение проблемы судебной защиты «законности», обещанное правительством накануне революции 1905 г., оказалось невозможным.

Описанные выше дискуссии о создании административных судов интересны во многих отношениях: как важный сюжет в истории политических взаимоотношений власти и оппозиции, как один из многих, но, тем не менее, своеобразный пример длительной подготовки реформы, так, впрочем, и не состоявшейся. В этом эссе мне хотелось бы привлечь внимание не столько к дискуссиям об институциональном оформлении реформы (как преобразовать Сенат или устроить местные суды), а к основным элементам правового мировоззрения, отразившимся в проектах реформ. Реформы правового контроля управления были затеяны во имя идеи законности. К спасительному идеалу законности не раз обращались монархи и политики, но именно накануне и в ходе революции 1905-1907 гг. эта идея приобрела особое значение и много разных интерпретаций. Участники дискуссий вкладывали в употребление этого юридического понятия вполне определенный смысл, в котором проявлялись как приверженность определенным западноевропейским

27. В.М. Гессен, О правовом государстве, СПб., 1907, с. 45.

28. См.: Законодательные проекты и предположения партии Народной Свободы: 19051907, СПб., 1907, с. 149; М. Петрункевич, Проект реформы земского самоуправления, выработанный в парламентской фракции партии Народной свободы, СПб., 1907, с. 63 (I Государственная Дума, Вып.2). 
концепциям и теориям, так и «история» этого термина в русской политикоюридической риторике.

Какую роль сыграли события 1904-1907 гг. в трансформации значения термина «законность»? Одним из главных последствий политического выбора правительства 12 декабря 1904 г. и конституционных реформ 1906 г. было то, что в политическом лексиконе «законность» оказалась на ступень ниже «конституции», а обращение к теме защиты законности воспринималось как альтернативный конституционным реформам путь. Ввиду сложившейся иерархии и соотношения терминов «конституция» и «законность», вполне резонным представляется увлечение П.А. Столыпина идеей контроля законности управления. Акцент на формальной «законности» как бы заполнял сферу реформ, на которое рассчитывало общество - эволюцию политических институтов от конституционно-самодержавного гибрида в сторону конституционной монархии. Для октябристов установление законности тоже было путем «нормализации» и усовершенствования политического строя без существенных правовых потрясений. Немецкая доктрина правового государства вполне соответствовала их политическим идеалам.

Для партий оппозиции, и, прежде всего, для кадетов, законность имела смысл только как необходимый, но вторичный компонент конституционной реформы. Не случайно, что проблеме «законности» и административного правосудия кадеты уделяли значительно меньше внимания, чем другие партии. Известный кадетский юрист Ф.Ф. Кокошкин признавал, что там, где принципы парламентаризма и парламентской ответственности правительства неосуществимы, особые органыс широкими правами по надзору зазаконностью управления могут «при известных благоприятных обстоятельствах» сыграть «полезную роль» ${ }^{29}$. В России, однако, такие условия едва ли существовали. Без конституционных реформ судебные гарантии законности были недостаточны. И все же, не отказываясь от обсуждения проектов административных судов, кадеты и прогрессисты следовали принципиально иным европейским стандартам, нежели октябристы и само правительство. Немецкой доктрине ограниченного правового государства они противопоставляли английскую теорию, согласно которой и государственные чиновники, и частные лица должны отвечать перед единым и равным для всех судом.

Таким образом, термин «законность», использовавшийся в политическом языке периода 1904-1917 гг., как и программы ее «охранения» были довольно разнообразны. Юридическая казуистика и исторические сложившиеся формы употребления этого понятия сформировали широкий спектр идей и концепций законности, требующий интерпретации. Как показывает анализ обсуждения двух основных правовых реформ - реформы Сената и административных судов, говоря о законности и правовом государстве, власть и общество вели диалог на разных языках. 